University of Nebraska - Lincoln

DigitalCommons@University of Nebraska - Lincoln

Entomology Papers from Other Sources

Entomology Collections, Miscellaneous

1985

Biochemical Evidence for Hybridization in Fire Ants

Robert K. Vander Meer

USDA

Clifford S. Lofgren

USDA

Francisco M. Alvarez

University of Florida

Follow this and additional works at: https://digitalcommons.unl.edu/entomologyother

Part of the Entomology Commons

Vander Meer, Robert K.; Lofgren, Clifford S.; and Alvarez, Francisco M., "Biochemical Evidence for Hybridization in Fire Ants" (1985). Entomology Papers from Other Sources. 32.

https://digitalcommons.unl.edu/entomologyother/32

This Article is brought to you for free and open access by the Entomology Collections, Miscellaneous at DigitalCommons@University of Nebraska - Lincoln. It has been accepted for inclusion in Entomology Papers from Other Sources by an authorized administrator of DigitalCommons@University of Nebraska - Lincoln. 


\title{
BIOCHEMICAL EVIDENCE FOR HYBRIDIZATION IN FIRE ANTS
}

\author{
ROBert K. VANDer Meer, Clifford S. Lofgren \\ USDA, Agricultural Research Service \\ Insects Affecting Man and Animals Research Laboratory \\ Gainesville, Florida 32604 \\ AND \\ Francisco M. Alvarez \\ Department of Entomology and Nematology \\ University of Florida \\ Gainesville, Florida 32611
}

Hybridization in social insects has been predicted on a theoretical basis by Pearson (1983); however, it is not a commonly reported phenomenon among ants. We recently found support for this theory when we discovered unique biochemical evidence for hybridization between Solenopsis invicta Buren and Solenopsis richteri Forel, two South American fire ant species that were inadvertently introduced into the southeastern United States. $S$. richteri was discovered in the Mobile, Alabama area about 1918, but it was quickly displaced by the more aggressive $S$. invicta (estimated to have been introduced in the early $1930 \mathrm{~s}$ ). At the present time, S. richteri is found only in northern Alabama and Mississippi (Lofgren et al. 1975).

Prior to being classifiied as two separate species (Buren 1972), S. invicta and $S$. richteri were considered extreme racial variations of Solenopsis saevissima (Wilson 1953, Wilson and Brown 1958). The taxonomy of the S. saevissima complex has undergone several transitions, having been described as containing eight species in 1930 (Creighton), then consolidated by Wilson (1952) to two species and one sub-species, and most recently expanded by Buren (1972) to six described species, including S. richteri and S. invicta.

Our investigation of hybridization evolved as a consequence of comparative behavioral and biochemical studies of $S$. invicta and S. richteri, including cuticular hydrocarbons and venom alkaloids. The venom of both 
S. richteri and S. invicta was characterized in the early 1970 s as 6 -methyl piperidine alkaloids with a variety of 2-substituted alkyl or alkenyl side chains (Brand et al. 1972). MacConnell et al. (1976) and Brand (1978) showed that the venom alkaloid composition of four Solenopsis species was species specific. S. richteri was easily differentiated from $S$. invicta by the absence of alkaloids with 15-carbon side chains and the presence of a high percentage of a piperidine with an 11-carbon side chain (Fig. 1). The distinctive alkaloid composition and morphological characteristics (Buren 1972) were used to define "pure" S. richteri and S. invicta. Thus, we were surprised to find that colonies collected around Starkville, Mississippi, "traditional" S. richteri territory, contained workers that were morphologically characterized as $S$. richteri, but that had venom gas chromatograph (GC) profiles (Fig. 1) characteristic of a blend of the two imported fire ant species. The hybrid contained the 15-carbon piperidine alkaloids characteristic of $S$. invicta and the 11-carbon alkaloids characteristic of S. richteri.

Further biochemical evidence for hybridization was obtained by comparison of species-specific hydrocarbons. Nelson et al. (1980) and Lok et al. (1975) identified the cuticular hydrocarbons of S. invicta and S. richteri as a series of normal, monomethyl and dimethyl branched hydrocarbons. The two species have distinctive patterns (Fig. 2, Vander Meer and Wojcik 1982). The major components of $S$. invicta are minor components of $S$. richteri and the major components of $S$. richteri are minor components of S. invicta. The hybrid again showed a blend of both S. invicta and S. richteri hydrocarbon patterns (Fig. 2).

Subsequent field collections and chemical analyses (colony workers were put in hexane for at least 2 days after which the solvent was removed and analyzed by GC for both venom alkaloids and hydrocarbons) showed that hybrid colonies predominated along highway 45 from Meridian to Starkville, Mississippi ( $95 \%$ hybrid, $5 \%$ S. invicta, $\mathrm{n}=22)$, and east and west of Starkville along highway 82 from Columbus to Eupora ( $82 \%$ hybrid, $18 \%$ $S$. richteri, $\mathrm{n}=22$ ). In contrast, pure $S$. richteri dominated collections made north of Starkville along highway 49 between West Point and Tupelo and alternate 45 between Columbus and Aberdeen $(74 \%$ S. richteri, $26 \%$ hybrid, $\mathrm{n}=27$ ). In every case hybridization was expressed in both the hydrocarbon and alkaloid patterns.

The hybridization event reported here was discovered serendipitously due to the biochemical expression of the hybrid and not due to morphological features. Whether this hybridization phenomenon also occurs in the ant's South American native habitat is not known at the present time. However, the widespread nature of the hybridization in the United States indicates that $S$. invicta and $S$. richteri can mate and produce viable colonies given the opportunity.

The accidental relocation of these two species to a totally new and apparently more favorable environment has allowed them to spread throughout the southern United States, and, if speciation holds true, must have removed pre-mating isolation mechanisms found in South America. This discovery provides a unique opportunity to study the ecology, taxonomy, behavior, and biochemistry of a naturally occurring hybridization event (at least non-laboratory induced). In addition, the implications of these results are many fold and bring up a number of questions. For example: 1) Was 


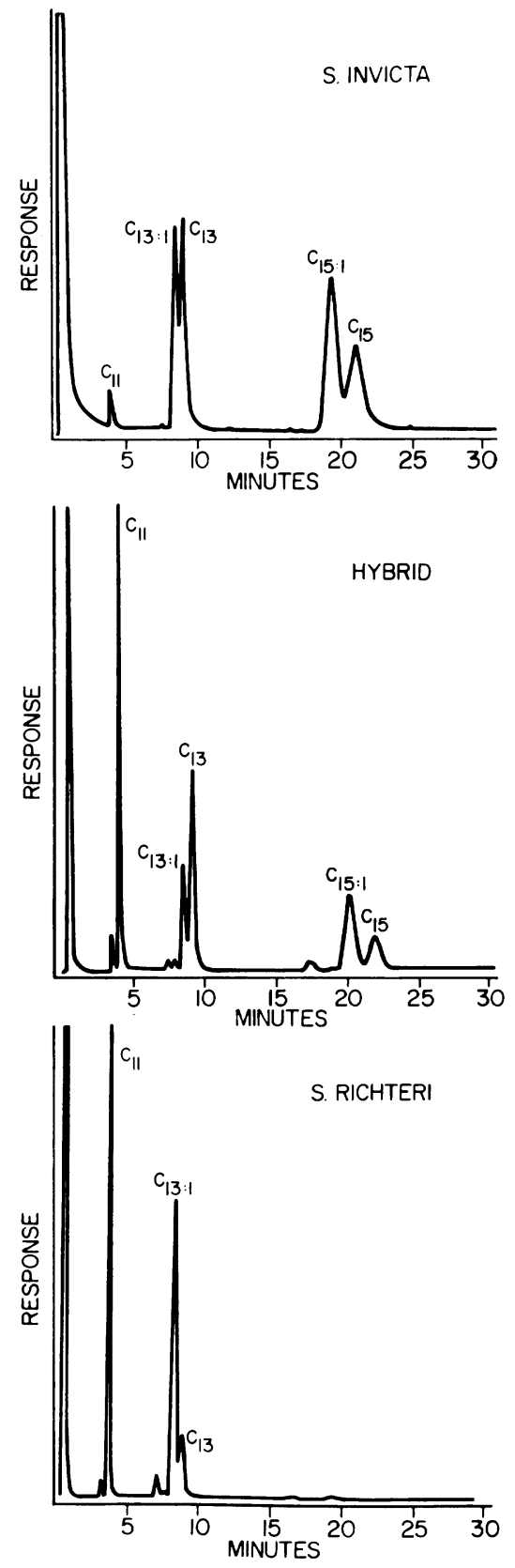

Fig. 1. Gas chromatogram traces of poison sac extracts (Varian 3700 , FID, $1.8 \mathrm{~m} \times 2 \mathrm{~mm}$ ID glass column packed with Superpak 20M, Analabs, New Haven, Connecticut; isothermal at $160^{\circ} \mathrm{C}$ ). Carbon numbers refer to the chain length and number of double bonds in the substituent at the 2position of the piperidine venom alkaloids (i.e., $\mathrm{C}_{15: 1}=6$-methyl-2-pentadecenyl piperidine). 

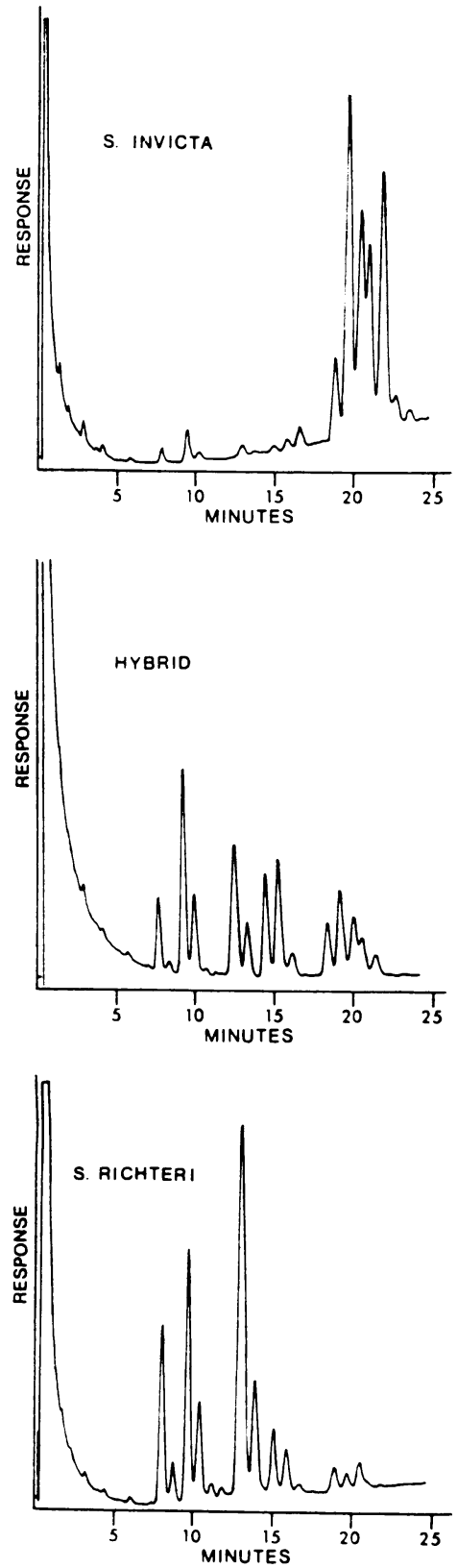

Fig. 2. Gas chromatogram traces of hydrocarbons from S. invicta, hybrid, and $S$. richteri (Varian 3700, FID, $1.8 \mathrm{~m} \mathrm{X} 2 \mathrm{~mm}$ ID glass column packed with OV-17 on $120 / 140$ chromsorb W; isothermal $205^{\circ} \mathrm{C}$ for 6 min. then to $240^{\circ} \mathrm{C}$ at $2 \%$ min.). 
the original $S$. richteri population out-competed or swamped both behaviorally and genetically? 2) What is the distribution in the U.S. of pure and hybrid S. richteri? 3) Will control methods established for S. invicta work equally well with the hybrid? 4) Is the hybrid more cold hardy? 5) What morphological features distinguish the hybrid from pure S. richteri? Many of these areas are currently under investigation.

Perhaps the most important question is whether or not S. richteri and $S$. invicta are indeed separate species, because the two major criteria used to assign species status were the lack of hybridization in the United States and the lack of phenotypic variability among the two populations (Buren 1972). Both of these criteria are negated by our findings, since hybridization is expressed biochemically and not obviously through morphological characters. An alternative hypothesis is that $S$. richteri and S. invicta are extreme forms or races of a Solenopsis super species (Wilson 1953, Wilson and Brown 1958).

It would appear that the ultimate answer to the fire ant taxonomic problem will be found in South America where ecological studies can provide information on possible pre-mating isolation mechanisms. Our results emphasize the volatile nature of Solenopsis taxonomy and supports the need to incorporate non-classical methods in modern taxonomic studies.

\section{REFERENCES CITED}

BARlin, M. R., M. S. BLUM, AND J. M. BRAND. 1976. Fire ant trail pheromones: analysis of species specificity after gas chromatographic fractionation. J. Insect Physiol. 22: 839-844.

BRAND, J. M. 1978. Fire ant venom alkaloids: their contribution to chemosystematics and biochemical evolution. Biochem. Syst. Ecol. 6: 337340.

Brand, J. M., M. S. Blum, H. M. Fales, and J. G. MacConnell. 1972. Fire ant venoms: comparative analyses of alkaloidal components. Toxicon 10: 259-271.

BuREN, W. F. 1972. Revisionary studies on the taxonomy of the imported fire ants. J. Georgia Entomol. Soc. 7: 1-27.

Buren, W. F., G. E. Allen, W. H. Whitcomb, F. E. Lennartz, and R. N. Williams. 1974. Zoogeography of the imported fire ants. J. New York Entomol. Soc. 82: 113-124.

Creighton, W. S. 1930. The new world species of the genus Solenopsis (Hymenoptera: Formicidae). Proc. Amer. Acad. Arts and Sci. 66: 39-151.

LoK, J. B., E. W. CuPP, AND G. J. Blomquist. 1975. Cuticular lipids of the imported fire ants, Solenopsis invicta and richteri. Insect Biochem. 5: $821-829$.

Lofgren, C. S., W. A. Banks, ANd B. M. Glancey. 1975. Biology and control of imported fire ants. Annu. Rev. Entomol. 20: 1-30.

MacConnell, J. G., M. S. Blum, W. F. Buren, R. N. Williams, and H. M. FALES. 1976. Fire ant venoms: chemotaxonomic correlations with alkaloidal compositions. Toxicon 14: 69-78.

Nelson, D. R., C. L. Fatland, R. W. Howard, C. A. McDaniel, and G. J. BLOMQUist. 1980. Re-analysis of the cuticular methylalkanes of Solenopsis invicta and S. richteri. Insect Biochem. 10: 409-418.

Pearson, B. 1983. Hydridization between the ant species Lasius niger and Lasius alienus: the genetic evidence. Insectes Sociaux 30: 402-411.

VANDer Meer, R. K., AND D. P. WoJcIK. 1982. Chemical mimicry in the 
myrmecophilous beetle Myrmecaphodius excavaticollis. Science 218: 806-808.

Wilson, E. O. 1952. The Solenopsis saevissima complex in South America (Hymenoptera: Formicidae). Mem. Inst. Oswaldo Cruz 50: 49-68.

Wilson, E. O. 1953. Origin of the variation in the imported fire ant. Evolution 7: 262-263.

WILson, E. O., AND W. L. BRown. 1958. Recent changes in the introduced population of the fire ant Solenopsis saevissima (Fr. Smith). Evolution 12: 211-218. 